\title{
Monitoring aseismic creep trends in the İsmetpaşa and Destek segments throughout the North Anatolian Fault (NAF) with a large-scale GPS network
}

\author{
Hasan Hakan Yavaşoğlu ${ }^{1}$, Mehmet Nurullah Alkan ${ }^{2}$, Serdar Bilgi $^{1}$, and Öykü Alkan ${ }^{3}$ \\ ${ }^{1}$ ITU, Dept. of Geomatics Engineering, Maslak, Istanbul, Turkey \\ ${ }^{2}$ Hitit University, Osmancik MYO, 19030, Corum, Turkey \\ ${ }^{3}$ ITU, Graduate School of Science Engineering and Technology, Maslak, Istanbul, Turkey
}

Correspondence: Hasan Hakan Yavasoglu (yavasoglu @itu.edu.tr)

Received: 25 July 2019 - Discussion started: 2 October 2019

Revised: 11 December 2019 - Accepted: 25 January 2020 - Published: 26 February 2020

\begin{abstract}
The North Anatolian Fault Zone (NAFZ) is an intersection area between the Anatolian and Eurasian plates. The Arabian Plate, which squeezes the Anatolian Plate from the south between the Eurasian Plate and itself, is also responsible for this formation. This tectonic motion causes the Anatolian Plate to move westwards with almost a $20 \mathrm{~mm} \mathrm{yr}^{-1}$ velocity, which has caused destructive earthquakes in history. Block boundaries that form the faults are generally locked to the bottom of the seismogenic layer because of the friction between blocks and are responsible for these discharges. However, there are also some unique events observed around the world, which may cause partially or fully free-slipping faults. This phenomenon is called "aseismic creep" and may occur through the entire seismogenic zone or at least to some depths. Additionally, it is a rare event in the world located in two reported segments along the North Anatolian Fault (NAF), which are İsmetpaşa and Destek.

In this study, we established GPS networks covering those segments and made three campaigns between 2014 and 2016. Considering the long-term geodetic movements of the blocks (Anatolian and Eurasian plates), surface velocities and fault parameters are calculated. The results of the model indicate that aseismic creep still continues with rates of $13.2 \pm$ $3.3 \mathrm{~mm} \mathrm{yr}^{-1}$ at İsmetpaşa and $9.6 \pm 3.1 \mathrm{~mm} \mathrm{yr}^{-1}$ at Destek. Additionally, aseismic creep behavior is limited to some depths and decays linearly to the bottom of the seismogenic layer at both segments. This study suggests that this aseis-
\end{abstract}

mic creep behavior will not prevent medium- to large-scale earthquakes in the long term.

\section{Introduction}

Fault zones all around the world are formed by tectonic plate motions and are natural boundaries between blocks. They are generally locked to the bottom of the seismogenic layer and cannot slip freely compared to the velocities within the blocks because of the friction between rocks. Therefore, movement in these regions is generally minimal and causes earthquakes when the motion of the blocks overrides the friction force. After discharge (earthquake), faults begin to accumulate strain and this cycle continues until the next earthquake (Reid, 1910; Yavaşoğlu, 2011).

The NAF (North Anatolian Fault) is a tectonic plate boundary between the Anatolian and Eurasian plates. It slowly moves at $\sim 20 \mathrm{~mm} \mathrm{yr}^{-1}$ to the west by the overthrusting Arabian Plate from the south and compresses the plate motion with the help of the massive Eurasian Plate in the north. Those tectonic forces constitute the North Anatolian Fault, which lies between the Karliova triple junction from the east and the Aegean Sea to the west for almost $1200 \mathrm{~km}$. The width of the fault trace ranges between $100 \mathrm{~m}$ and $10 \mathrm{~km}$. The Anatolian Plate moves $20-25 \mathrm{~mm} \mathrm{yr}^{-1}$ to the west relative to the Eurasian Plate. There are velocity variations along the fault; that is, the west region moves faster than the eastern part and is a right-lateral strike-slip fault (Fig. 1) (Ketin, 


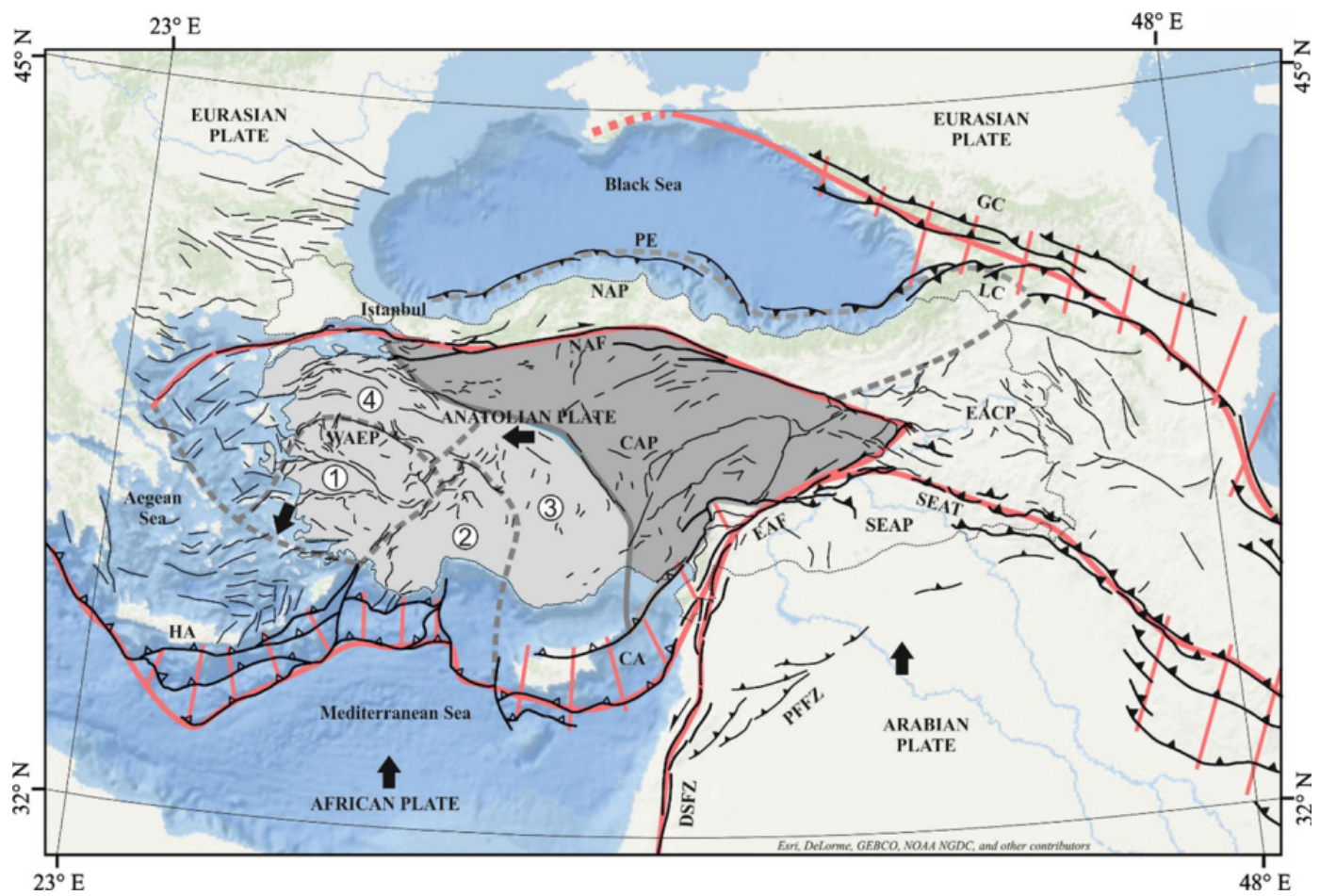

Figure 1. Formation of the North Anatolian Fault and interacting tectonic plates (from Emre et al., 2018). The Anatolian Plate moves westwards due to African and Arabian plate overthrusting. (1) Western Anatolian graben systems, (2) outer Isparta Angle, (3) inner Isparta Angle and (4) the northwest Anatolia transition zone. The original version of the figure is available in Emre et al. (2018).

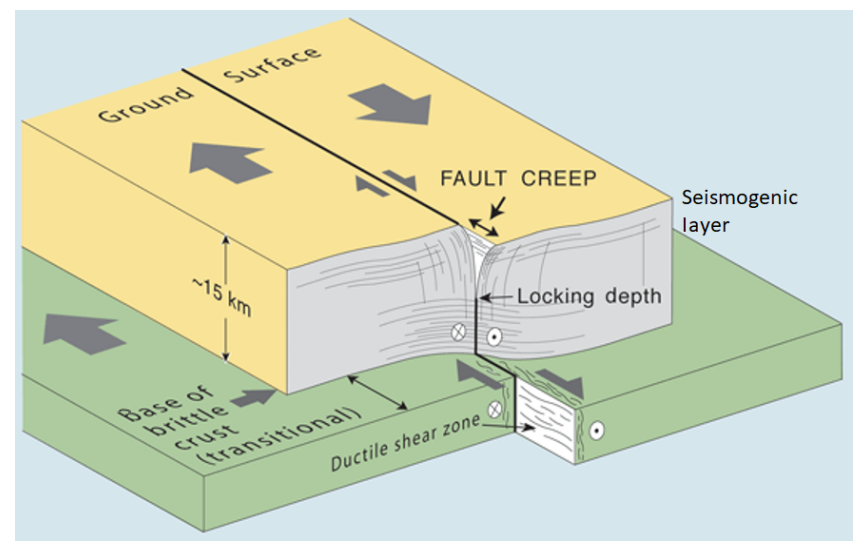

Figure 2. Aseismic creep structure in a fault zone. The fault may slip freely to some depths and afterwards is locked to the bottom (http://funnel.sfsu.edu/creep/WhatsCreepPage.html, last access: 19 December 2018).

1969, 1976; McClusky et al., 2000; Cakir et al., 2005; Şengör et al., 2005; Reilinger et al., 2006; Yavaşoğlu et al., 2011; Bohnhoff et al., 2016).

Earthquake mechanisms might have different characteristics in some regions. Faults may move freely without an earthquake, and this motion is reported at some unique places like the Hayward fault (Schmidt et al., 2005), the Supersti- tion Hills fault (Wei et al., 2011) and the İsmetpaşa segment (Cakir et al., 2012), which can be observed from the surface (Ambraseys, 1970; Yavasoglu et al., 2015). This phenomenon is called "aseismic creep" and may occur in two different ways. If the creep takes place to the bottom of the seismogenic layer and the surface velocities are equal or close to the long-term tectonic velocities, there will not be enough strain accumulation for a large-scale earthquake (Şaroğlu and Barka, 1995; Cakir et al., 2005). On the other hand, if that free motion is not observed to the bottom of the seismogenic layer or observed surface velocities are smaller than the tectonic velocities, strain will accumulate to a final earthquake (Fig. 2) (Karabacak et al., 2011; Ozener et al., 2013; Yavasoglu et al., 2015). Also, aseismic creep in a region may occur continuously or fade out after some period (Kutoglu et al., 2010).

The NAF is reported to have segments that have shown aseismic creep since 1970 at İsmetpaşa, with a more recent discovery at Destek (Ambraseys, 1970; Karabacak et al., 2011). Aseismic creep at İsmetpaşa is reported to occur along $\sim 70-80 \mathrm{~km}$, from Bayramören (east) to the Gerede (west) (Fig. 3). It was discovered at the wall of the İsmetpaşa train station in 1970, and several minor and large-scale studies have monitored the area since then (Table 1). That segment has hosted three destructive earthquakes (1943 Tosya $M_{\mathrm{w}}=$ 7.2, 1944 Gerede $M_{\mathrm{w}}=7.2,1951$ Kursunlu $M_{\mathrm{w}}=6.9$ ) that 


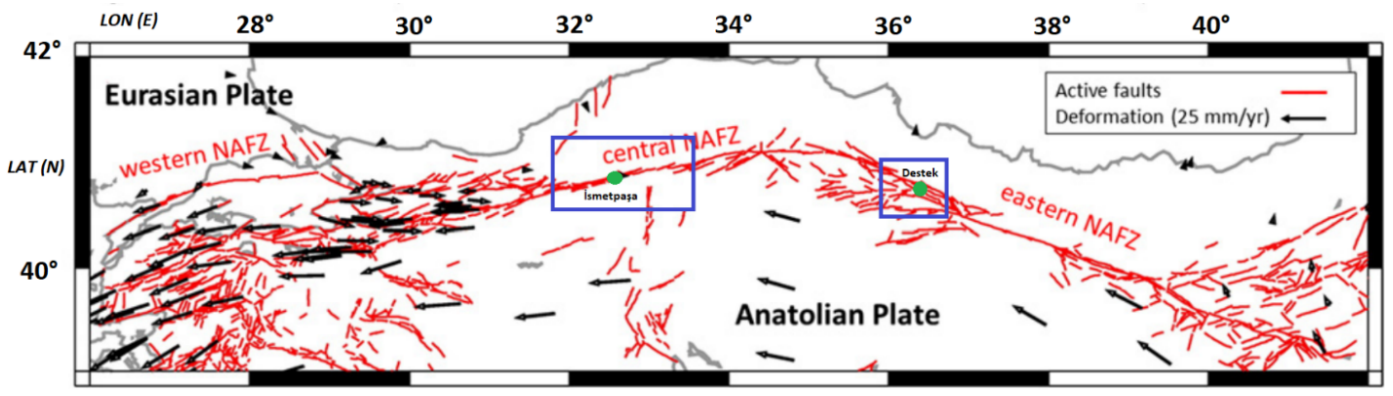

Figure 3. Active fault segments on the North Anatolian Fault (NAF). Blue rectangles define the İsmetpaşa and Destek segments from west to east, respectively (after Bohnhoff et al., 2016).

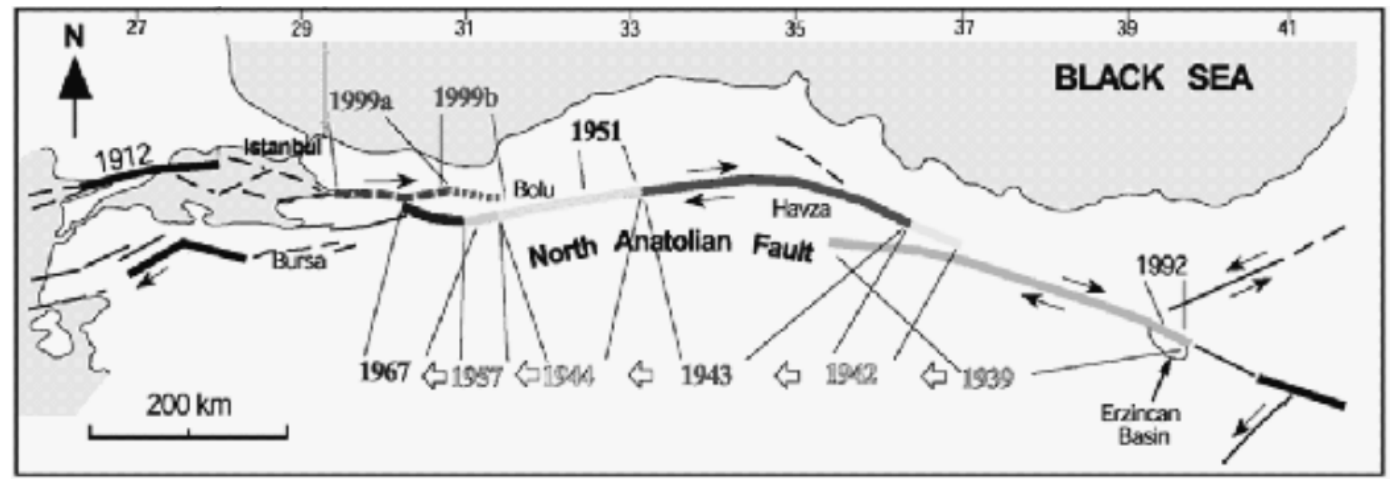

Figure 4. Earthquakes on the North Anatolian Fault between 1939 and 1999. Both the 1943 and 1944 earthquakes are suspected to have had an influence on the creeping phenomena (from Kutoglu et al., 2010).

may have triggered or affected the creep (Şaroğlu ve Barka, 1995; Cakir et al., 2005; Karabacak et al., 2011; Kaneko et al., 2013) (Fig. 4).

In addition, creep at the Destek segment was reported in 2003 on a field trip around the region. Unlike the İsmetpaşa segment, there are few studies at this segment, and also the length of this segment is unclear. The 1943 Tosya earthquake, which is reportedly the biggest earthquake in the segment, affected this area (Karabacak et al., 2011) (Table 2).

All the studies around those segments indicate the continuity of creep, but the results are inconsistent and cannot clearly identify whether that event has an increasing trend or not. Most research (Ambraseys, 1970; Aytun, 1982; Eren, 1984; Altay and Sav, 1991; Deniz et al., 1993; Kutoglu et al., 2008, 2009, 2013; Karabacak et al., 2011; Ozener et al., 2013; Bilham et al., 2016) is generally on a microscale and focused on İsmetpaşa or a network near this village with geodetic methods, while others focus on a macroscale with InSAR (Deguchi, 2011; Fialko et al., 2011; Köksal, 2011; Kaneko et al., 2013; Cetin et al., 2014; Kutoglu et al., 2013), which needs a ground truth (Figs. 5, 6).

Those results cannot reveal the creep trend clearly. In addition, a ground network is required to exhibit the fault characteristics clearly along the segments. For this reason, we established a ground network to form profiles around those segments and made three observations annually from 2014 to 2016 .

\section{Network design around the creeping segments}

Designing a monitoring network around tectonic structures is always related to the geological characteristics and fault geometry, which includes the locking depth and earthquakerelated motions (coseismic movements) through the fault. Previous studies indicate that the velocities for the stations distant from the fault plane can be used to derive long-term plate velocities, while nearby station velocities are suitable to detect the locking depth of a fault (Taskin et al., 2003; Halıcıoğlu et al., 2009). In addition, the velocities of the observation stations gradually decrease when their locations approach the fault plane. Another factor is the number of stations, and this is related to the fault length and width, but the station locations perpendicular to the fault plane must not exceed $( \pm 1 / \sqrt{ } 3)$ of the locking depth. Also, some research has specified this limit as double the depth (Taskin et al., 2003; Kutoglu and Akcin, 2006; Kutoğlu et al., 2009; Halıcioğlu et al., 2009; Poyraz et al., 2011; Bohnhoff et al., 2016). For this purpose, the following equation is used in general to obtain the proper distances of the observation stations from the fault 

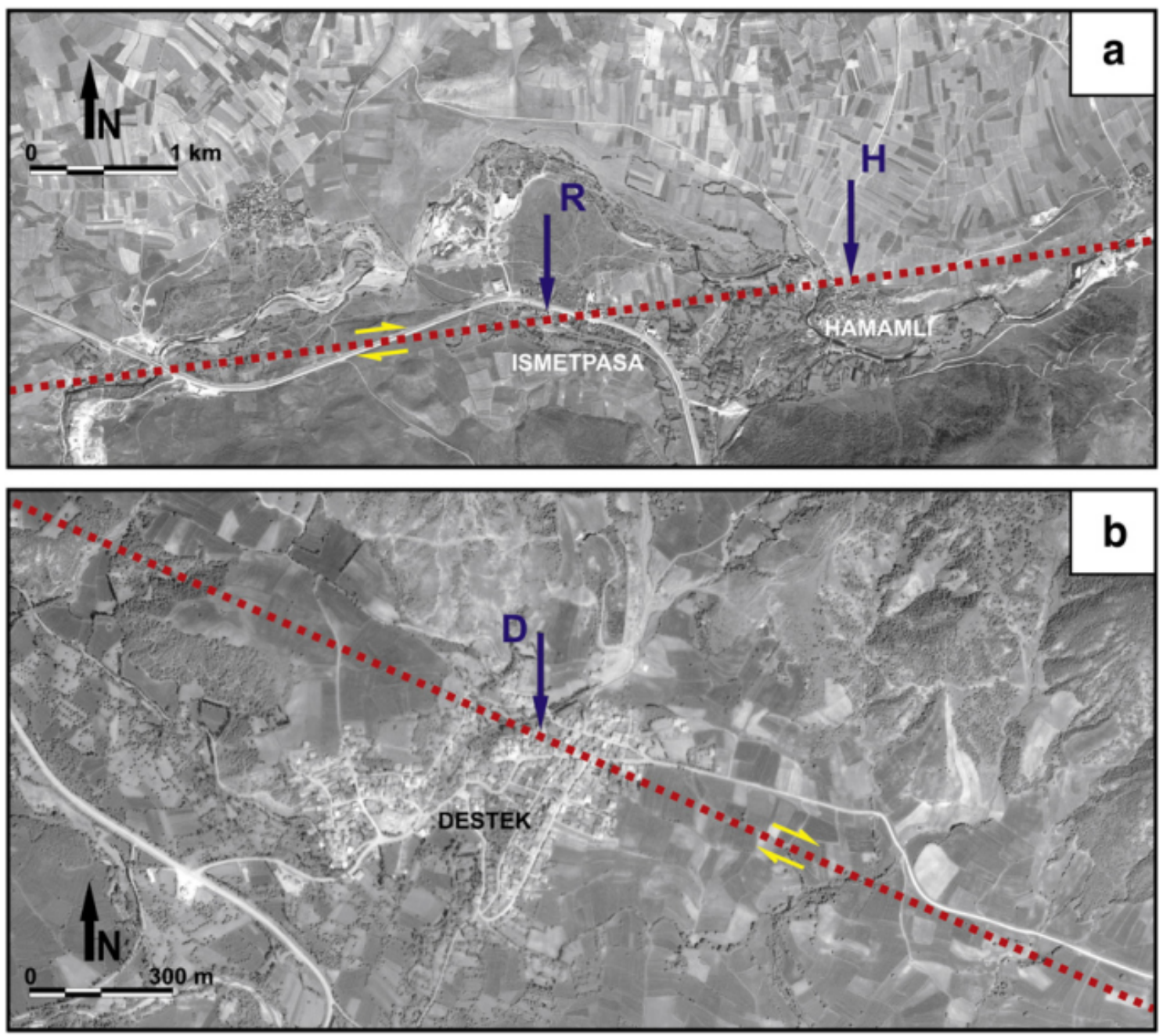

Figure 5. Reported aseismic creep zones at İsmetpaşa (a) and Destek (b) segments from a recent study. (a) R shows creep observed at the wall at the İsmetpaşa train station, and $\mathrm{H}$ shows the creep at Hamamlı village. (b) D represents the reported creep at Destek town (from Karabacak et al., 2011).

plane:

$V(x)=\frac{V_{\mathrm{T}}}{\pi} \arctan \left(\frac{x}{D}\right)$,

where $V$ is the fault-parallel velocity, $V_{\mathrm{T}}$ is the long-term tectonic plate velocity, $x$ is the distance to the fault plane and $D$ is the locking depth of the fault (Halıcıoglu et al., 2009).

The location of the stations may vary according to the geological surface elements, but they are generally established on both sides of the fault to form a profile on each block to obtain surface velocities (Yavasoglu et al., 2015).

The geologic structure at the tectonic block boundaries and fault plane geometry also affect the tectonic behavior. To better understand this mechanism, an established network around the fault zone is observed with different techniques periodically or continuously. The variation of the observations is a clue to detect those amplitudes, and GPS is the most common technique for that kind of study. This technique is very effective and efficient to collect data from ground stations established around faults (Poyraz et al., 2011; Aladoğan et al., 2017).

Profiles that intersect the fault plane vertically are used to estimate the locking depth. However, in regions like İsmetpaşa and Destek, there is an additional locking depth deduced from the previous studies, which indicates that the creeping layer of the seismogenic zone does not reach the bottom but is around 5-7 km of depth in those areas (Kaneko et al., 2013; Ozener et al., 2013; Cetin et al., 2014; Bilham et al., 2016; Rousset et al., 2016). For this reason, the aseismic layer's attenuation depth is another crucial element to understand the creeping mechanism (Fig. 2). Also, considering the 5-7 km depth value with Eq. (1), station locations are chosen as 3 and $10 \mathrm{~km}$ on both sides of the fault to form profiles, while the NAF general locking depth is around $15 \mathrm{~km}$ (McClusky et al., 2000; Poyraz et al., 2011; Bohnhoff et al., 2016). 

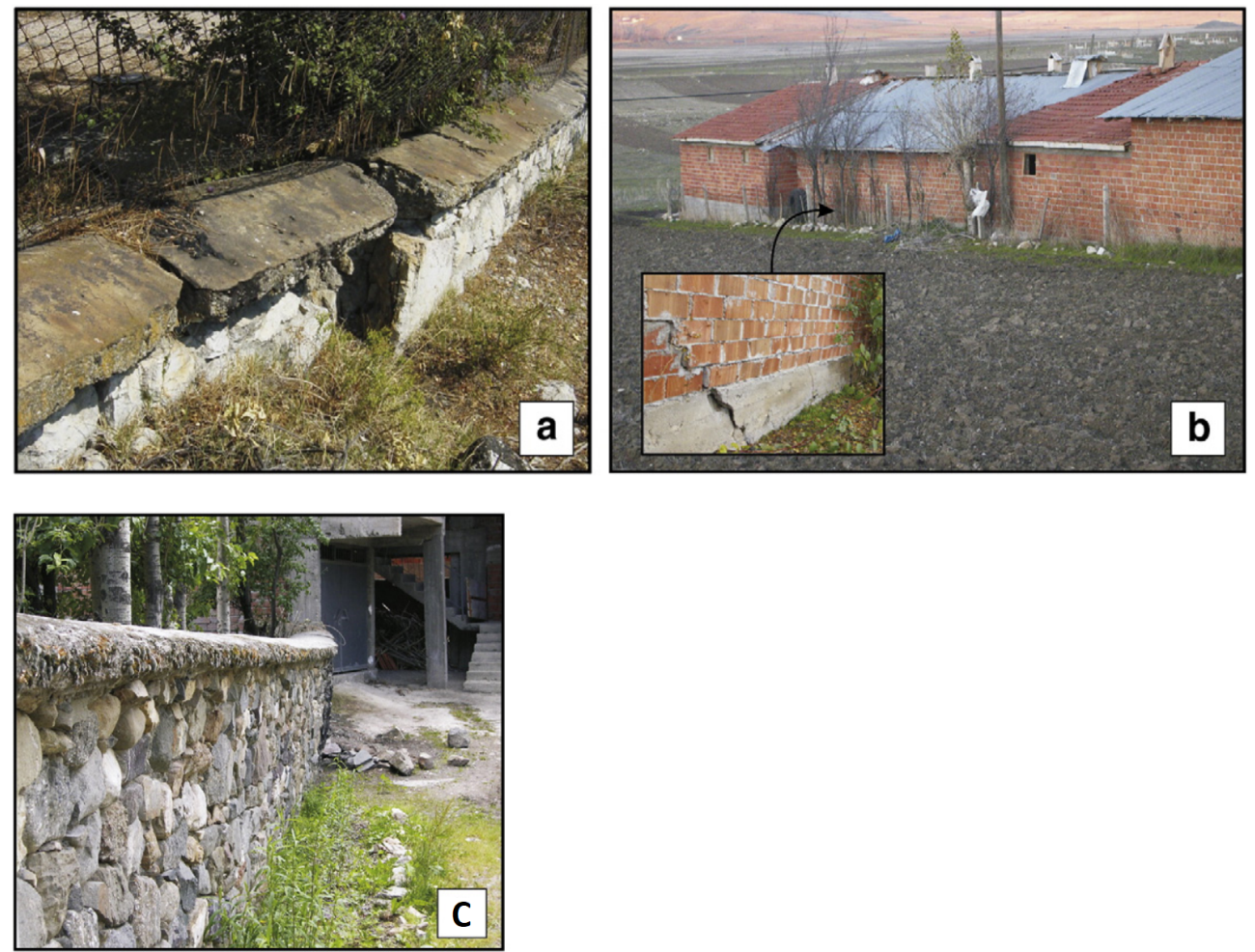

Figure 6. Aseismic creep sites (a) at İsmetpaşa railway station and (b) a damaged brick wall at Hamaml village close to İsmetpaşa. (c) Outbent wall at Destek village (from Karabacak et al., 2011).

Table 1. Studies and their results to observe aseismic creep at the İsmetpaşa segment between 1970 and 2016.

\begin{tabular}{lrrl}
\hline Study & Creep rate $\left(\mathrm{cm} \mathrm{yr}^{-1}\right)$ & Years covered & Method \\
\hline Ambraseys (1970) & $2.0 \pm 0.6$ & $1957-1969$ & Wall offset measurements \\
Aytun (1982) & $1.10 \pm 0.11$ & $1969-1978$ & Doppler \\
Eren (1984) & $1.00 \pm 0.40$ & $1972-1982$ & Trilateration \\
Deniz et al. (1993) & $0.93 \pm 0.07$ & $1982-1992$ & Trilateration \\
Cakir et al. (2005) & $0.80 \pm 0.30$ & $1992-2000$ & InSAR \\
Kutoglu and Akcin (2006) & $0.78 \pm 0.05$ & $1992-2002$ & GPS \\
Kutoglu et al.(2008) & $1.20 \pm 0.11$ & $2002-2007$ & GPS \\
Kutoglu et al. (2010) & $1.51 \pm 0.41$ & $2007-2008$ & GPS \\
Karabacak et al. (2011) (one region) & $0.84 \pm 0.40$ & $2007-2009$ & Lidar \\
Karabacak et al. (2011) (two regions) & $0.96 \pm 0.40$ & $2007-2009$ & Lidar \\
Deguchi (2011) & 1.4 & $2007-2011$ & PALSAR \\
Fialko et al. (2011) & 1.0 & $2007-2010$ & PALSAR \\
Ozener et al. (2013) & $0.76 \pm 0.10$ & $2005-2011$ & GPS \\
Köksal (2011) & $1.57 \pm 0.20$ & $2007-2010$ & DInSAR \\
Görmüş (2011) & $1.30 \pm 0.39$ & $2008-2010$ & GPS \\
Kaneko et al. (2013) & $0.9 \pm 0.2$ & $2007-2011$ & InSAR \\
Cetin et al. (2014) & $0.8 \pm 0.2$ & $2003-2010$ & InSAR(PSI) \\
Altay and Sav (1991) & $0.76 \pm 0.1$ & $1982-1991$ & Creepmeter \\
Kutoglu et al. (2013) & $1.3 \pm 0.2$ & $2008-2010$ & GPS \\
Kutoglu et al. (2013) & $1.25 \pm 0.2$ & $2007-2010$ & InSAR \\
Ambraseys (1970), Bilham et al. (2016) revision & $1.04 \pm 0.04$ & $1957-1969$ & Revaluation of photographs \\
Aytun (1982) & 1.50 & $1957-1969$ & Revaluation of photographs \\
Aytun (1982), Bilham et al. (2016) revision & $1.045 \pm 0.035$ & $1957-1969$ & Revaluation of photographs \\
Bilham et al. (2016) & $0.61 \pm 0.02$ & $2014-2016$ & Creepmeter \\
\hline
\end{tabular}


Table 2. Studies and their results to observe aseismic creep at the Destek segment.

\begin{tabular}{lrrr}
\hline Study & Creep rate $\left(\mathrm{cm} \mathrm{yr}^{-1}\right)$ & Years covered & Method \\
\hline Karabacak et al. (2011) & $0.66 \pm 0.40$ & $2007-2009$ & Lidar \\
Fraser et al. (2009) & 0.6 & 2009 & Trench study \\
\hline
\end{tabular}
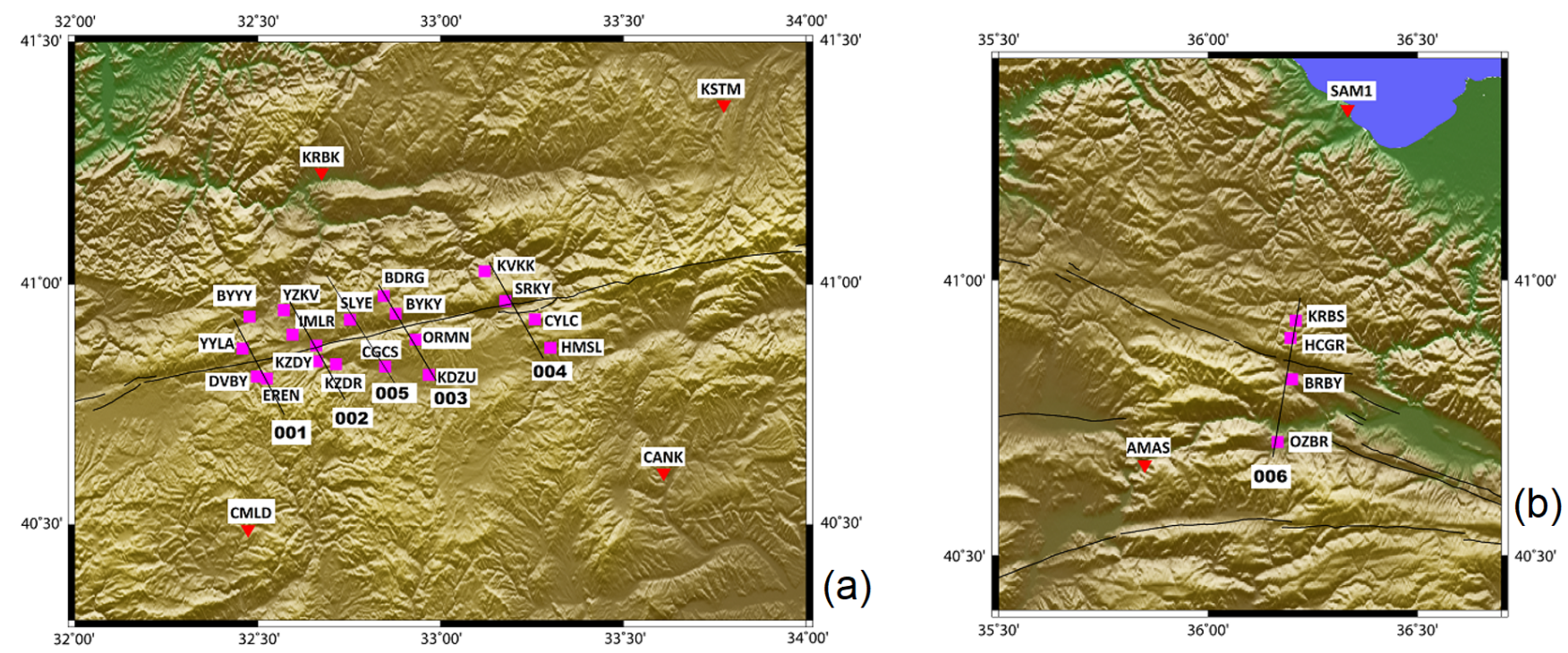

Figure 7. Planned profiles and campaign GPS stations(pink) at İsmetpaşa (a) and Destek (b). Profiles 001-004 are planned and established on the İsmetpaşa segment, and profile 005 is added to the network using two suitable stations. Profile 006 is on the Destek segment. Fault traces on the south of profile 006 are secondary faults. Other continuous GPS sites (RTK CORS) are shown in red (after Yavasoglu et al., 2015).

Before the three observation periods, a network was planned to form four profiles at İsmetpaşa and one profile at the Destek segment, including surrounding continuous GPS stations (real-time kinematic continuously operating reference stations - RTK CORSs) (Fig. 7). The aim of this study was to monitor this network periodically to calculate the velocity field and combine the results with CORS station velocities to estimate the creep ratio within the İsmetpaşa and Destek segments (Yavasoglu et al., 2015).

While establishing the network, 3 and $10 \mathrm{~km}$ on both sides of the fault were first considered, but some minor changes took place according to the geological structure of the area. In addition, another profile between the second and third profiles was formed with the suitable location of two unplanned stations. Finally, there are five profiles within $\sim 70 \mathrm{~km}$ along İsmetpaşa and one profile along Destek.

Observations were completed around July and August for 3 years using relative geolocations based on carrier-phase observations with the GPS technique (Table 3). Force centering equipment and GPS masts were used when necessary. The first campaign was on the 235-238 and 241 GPS days in 2014, the second was on 215-221 GPS days in 2015, and the last one was between 210 and 220 GPS days in 2016 .
After the first campaign, KZDY station was damaged and removed from the rest of the project. Raw data collected for a minimum of $8 \mathrm{~h}$ at each station for the rest of the project were evaluated with GAMIT/GLOBK software (Herring et al., 2015a, 2015b) first, then the results were used as input to the block modeling software TDEFNODE (McCaffrey, 2002, 2009). A total of 63 stations (22 campaign, 30 surrounding RTK CORS, 11 IGS) are used in this network to monitor the İsmetpaşa and Destek segments and the remaining region between them (Table 4).

\section{GPS data evaluation}

GPS data for cGPS and the IGS station data were processed on campaign observation dates. In addition, observations for those stations during January (for $7 \mathrm{~d}$ ) were included at the GAMIT/GLOBK step to increase the stabilization of the designed networks.

The networks were linked to the ITRF 2008 global coordinate system by using surrounding IGS sites (Table 5) (Yavaşoglu et al., 2011; Herring et al., 2015a, b). After the transformation with GLOBK, the root mean square (RMS) of the stations was only $0.7 \mathrm{~mm} \mathrm{yr}^{-1}$. 
Table 3. Campaign stations, their locations and facility types.

\begin{tabular}{|c|c|c|c|c|c|}
\hline Profile number & $\begin{array}{l}\text { Station } \\
\text { ID }\end{array}$ & Site & Latitude $\left({ }^{\circ}\right)$ & Longitude $\left({ }^{\circ}\right)$ & $\begin{array}{l}\text { Type of } \\
\text { facility }\end{array}$ \\
\hline \multirow{4}{*}{001} & BYYY & Büyükyayalar & 40.49 & 32.48 & Bronze \\
\hline & YYLA & Yayla village & 41.45 & 31.78 & Bronze \\
\hline & DVBY & Davutbeyli village & 39.43 & 32.50 & Bronze \\
\hline & EREN & Elören village & 40.81 & 32.50 & Bronze \\
\hline \multirow{4}{*}{002} & YZKV & Yazıkavak village & 40.80 & 32.53 & Bronze \\
\hline & IMLR & İmanlar village & 40.95 & 32.57 & Bronze \\
\hline & HMMP & Hamamlı village & 40.90 & 32.60 & Pillar \\
\hline & KZDR & Kuzdere village & 41.23 & 32.68 & Pillar \\
\hline \multirow{2}{*}{005 (intermediate) } & SLYE & Kapaklıvillage & 41.85 & 32.72 & Pillar \\
\hline & CGCS & D100 wayside & 39.86 & 32.85 & Pillar \\
\hline \multirow{4}{*}{003} & BDRG & Boduroğlu village & 39.89 & 32.76 & Bronze \\
\hline & BYKY & Beyköy village & 40.83 & 32.85 & Pillar \\
\hline & ORMN & Forest & 40.94 & 32.86 & Bronze \\
\hline & KDZU & Kadıözü village & 40.88 & 32.93 & Pillar \\
\hline \multirow{4}{*}{004} & KVKK & Kavak village & 40.81 & 32.97 & Bronze \\
\hline & SRKY & Sarıkaya village & 41.03 & 33.12 & Bronze \\
\hline & CYLC & Çaylıca village & 40.97 & 33.18 & Bronze \\
\hline & HMSL & Hacımusla village & 40.93 & 33.26 & Pillar \\
\hline \multirow{4}{*}{006} & KRBS & Korubaşıvillage & 40.82 & 36.20 & Bronze \\
\hline & HCGR & Hacıgeriç village & 40.71 & 36.17 & Bronze \\
\hline & BRBY & Borabay & 40.90 & 36.20 & Pillar \\
\hline & OZBR & Özbaraklıvillage & 39.66 & 35.87 & Pillar \\
\hline
\end{tabular}

Table 4. Continuous GPS (RTK CORS) stations and their locations.

\begin{tabular}{llllll}
\hline Station ID & Province & Station ID & Province & Station ID & Province \\
\hline AKDG & Yozgat & FASA & Ordu & RDIY & Tokat \\
AMAS & Amasya & GIRS & Giresun & SAM1 & Samsun \\
ANRK & Ankara & HEND & Sakarya & SIH1 & Eskişehir \\
BILE & Bilecik & HYMN & Ankara & SINP & Sinop \\
BOLU & Bolu & IZMT & İzmit & SIVS & Sivas \\
BOYT & Sinop & KKAL & Kırıkkale & SSEH & Sivas \\
CANK & Çankırı & KRBK & Karabük & SUNL & Çorum \\
CMLD & Ankara & KSTM & Kastamonu & TOK1 & Tokat \\
CORU & Çorum & KURU & Bartın & VEZI & Samsun \\
ESKS & Eskişehir & NAHA & Ankara & ZONG & Zonguldak \\
\hline
\end{tabular}

Results show that the velocity of the stations located on the Anatolian Plate range from 15 to $20 \mathrm{~mm} \mathrm{yr}^{-1}$ (Fig. 8), which is similar to previous studies (McClusky et al., 2000; Reilinger et al., 2006; Yavaşoglu et al., 2011).

The GLOBK results for all of the station velocities are used as input for block modeling to predict the aseismic creep ratio within the fault plane in the predefined segments (Table 6, Fig. 9).

The aseismic creep ratio is estimated by interpolation through the profiles using surface velocities except the third profile (Table 7).
The GAMIT process indicates abnormal deformation for the ORMN and KDZU campaign stations, so their data are removed from the block modeling step. Additionally, the creep estimation for that profile is unfeasible. Actually, this is not a drawback for block modeling because the remaining station velocities are all used to model the region uneventfully.

With the calculated surface velocities, the Destek segment also has a creep trend through the campaign period. The estimated creep rate in this study according to GLOBK results is $10.6 \pm 3.1 \mathrm{~mm} \mathrm{yr}^{-1}$ in this region, and it indicates aseismic 


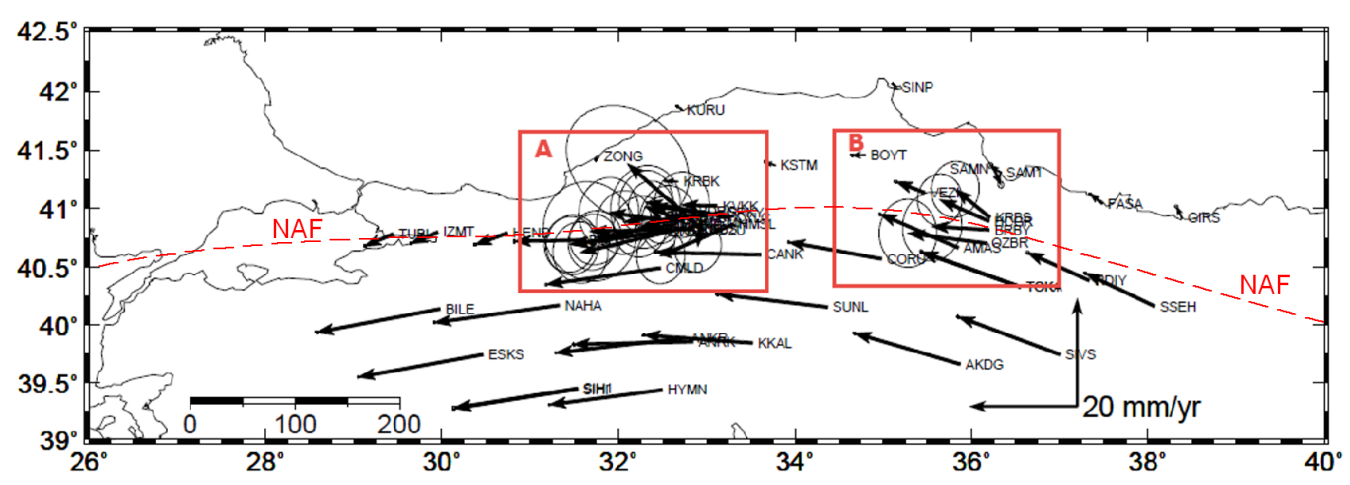

Figure 8. GLOBK results for station velocities relative to the fixed Eurasian Plate. (a) The İsmetpaşa segment and (b) the Destek segment. Dashed lines represent the fault trace of the North Anatolian Fault (NAF). Velocities at the north of the NAF are very small as expected, and south velocities indicate the westward motion of the Anatolian Plate (after Aladoğan, 2017).

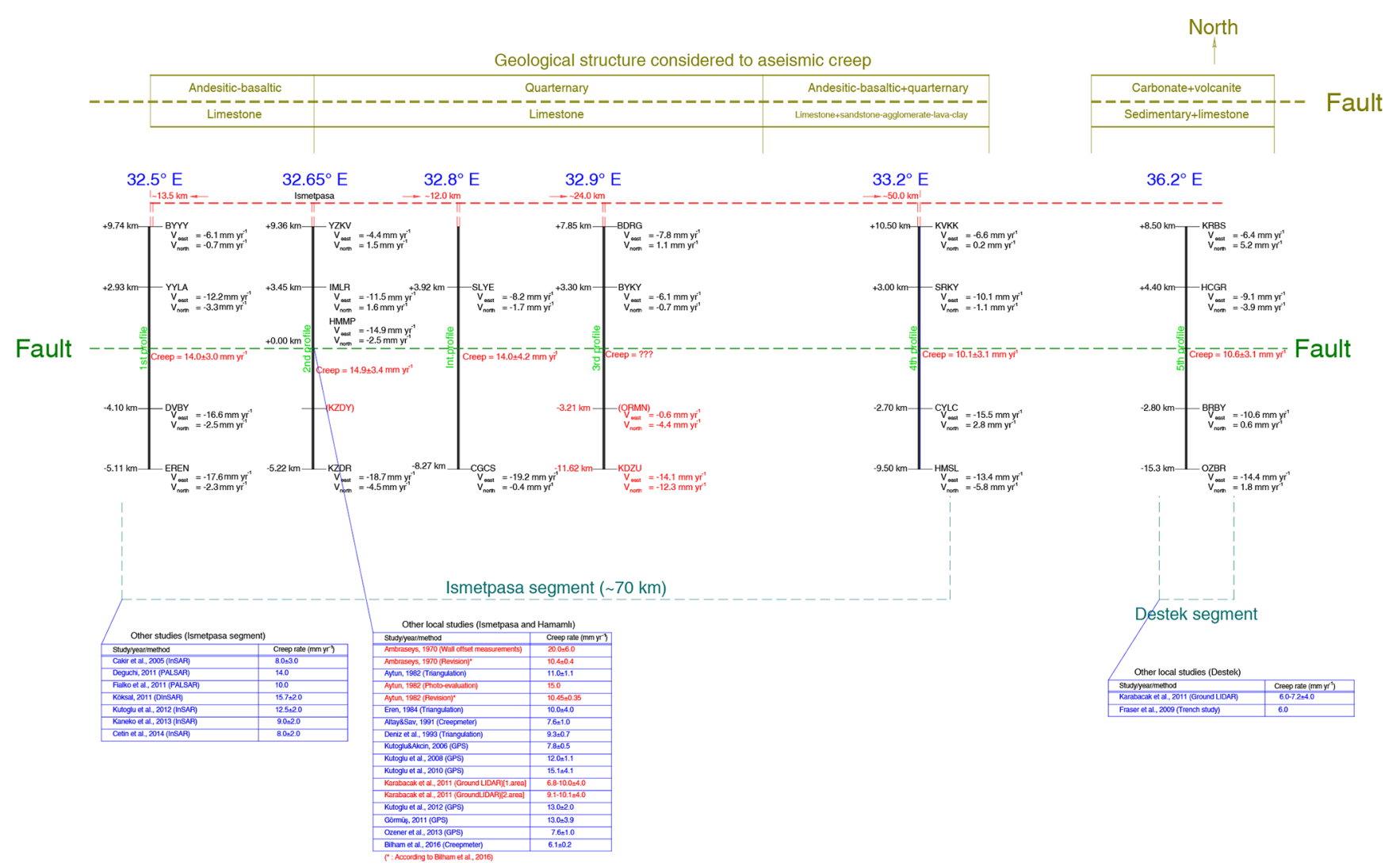

Figure 9. Geological structure related to aseismic creep, station velocities, estimated creep ratio, and earlier studies around the İsmetpaşa and Destek regions (Akbaş et al., 2002; Cetin et al., 2014).

creep similar to recent studies (Fraser et al., 2009; Karabacak et al., 2011).

\section{Block modeling}

Station velocities are suitable to predict surface and block motions locally. On the other hand, observations inside the blocks provide adequate long-term block velocities and ro- tations with high precision. Blocks generally demonstrate a regular movement, but their motion differs at their boundaries from this overall velocity. They cannot move freely around the faults because of the friction of rocks, which is generally interpreted as a slowdown that may eventually result in a total lack of movement (Fig. 10). That difference in velocity is called "slip deficit" and causes earthquakes after 
Table 5. IGS stations defined in the site.defaults file of GAMIT to constitute a reference frame.

\begin{tabular}{ll}
\hline Station ID & City, country \\
\hline ANKR & Ankara, Turkey \\
BUCU* & Bucharest, Romania \\
CRAO* & Simeiz, Ukraine \\
MATE* & Metara, Italy \\
ONSA* & Onsala, Switzerland \\
SOFI* & Sofia, Bulgaria \\
TEHN* & Tehran, Iran \\
TELA & Tel Aviv, Israel \\
TUBI & Kocaeli, Turkey \\
WZTR* & Koetzting, Germany \\
ZECK* & Zelenchukskaya, Russia \\
\hline * Indicates stations selected for GLOBK \\
stabilization.
\end{tabular}

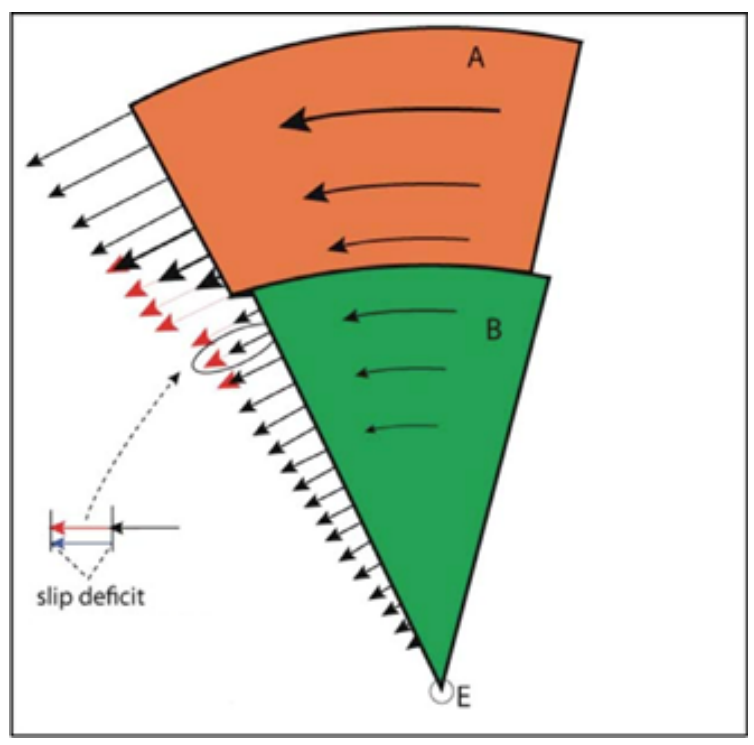

Figure 10. Motions of tectonic blocks around the same Euler pole and slip deficit at their boundaries. Long-term block velocities evolve at the fault zones, and the gap between them is responsible for strain accumulation and earthquakes (from Cakmak, 2010).

the friction threshold is surpassed (Kutoglu and Akcin, 2006; McCaffrey, 2014; Yavasoglu et al., 2015).

Slip deficit represents that expected velocities of the blocks pass through some deformations regarding the geological structure when approaching the fault zone and frequently decreases. This is based on the geometry of the fault plane, which can only be predicted based on surface velocities. In that context, the TDEFNODE software was used in this study to predict the fault plane locking interaction regarding the depths, which calculates variations of the block motions, strain accumulation within the blocks, and rotations through interseismic or coseismic periods (Okada, 1985; McCaffrey, 2009; Yavaşoğlu, 2011).

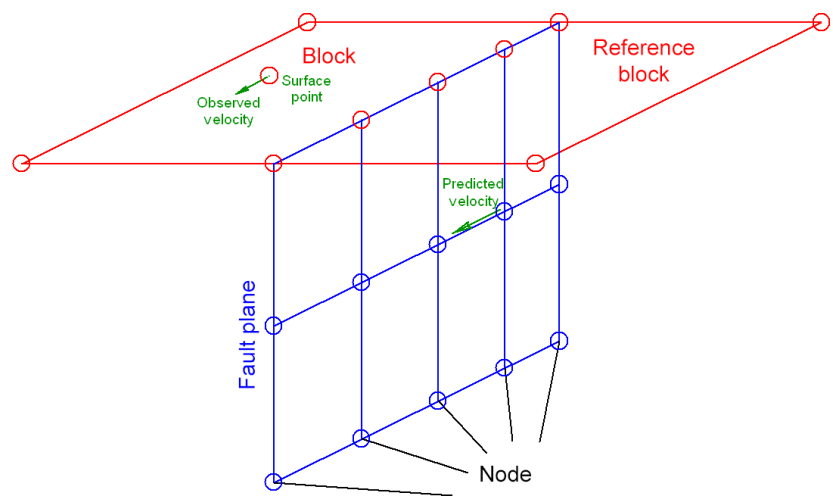

Figure 11. Fault plane geometry defined in the control file of TDEFNODE (http://www.web.pdx.edu/ mccaf/defnode.html, last access: 20 December 2018) (after DiZio, 2016). The node divides the fault plane into subregions with defined depths, and their locking ratios may differ from each other.

Basic input for the software includes GPS velocities, blocks with Euler poles, fault geometry and locking depth. Interacting blocks are represented as elastic blocks and are assumed to have elastic deformation because of their rotation around Euler poles. All of the defined system is assumed to float inside a half-space in which one of the blocks is fixed and has zero strain or movement. Fault geometry is defined by the user with nodes, and their locking ratios (phi) can be defined manually or as a function of depth (Fig. 11). Then, the software predicts the underground velocities based on the routines of Okada (1985) and estimates the surface velocities according to the defined values. Fault geometry estimation is the key feature to minimize the difference between observed and predicted surface velocities with the help of the $\chi^{2}$ test result, which represents the accuracy of the entire model (McCaffrey, 2002; Aktuğ and Çelik, 2008; Yavasoglu et al., 2011).

TDEFNODE is not only used for interacting blocks for interseismic strain accumulation, but also for faults that are partially or fully free-slipping like aseismic creep. The software model is suitable to define the locking ratios of all nodes independently for $(0-1)$. (0) represents the fault at that node freely slipping, and (1) is for a fully locked node. That allows the user to define the fault plane with layers by using depth contours and to predict the fault plane if those layers are partially or fully locked (http://www.web.pdx.edu/ $\sim$ mccaf/defnode.html, last access: 20 December 2018).

Aseismic creep is an earthquake-free motion along the Earth's surface, but in some cases it is difficult to detect whether this motion is a free-slipping event or an interseismic movement. Thus, the observation network around the fault plane should be planned carefully regarding the $\pm 3-10 \mathrm{~km}$ station locations mentioned before (Fig. 12).

During the TDEFNODE process, one of the tectonic blocks should be chosen as fixed to estimate the fault param- 
Table 6. All cGPS, campaign point velocities and location errors (uncertainties) when the Eurasian Plate is selected as fixed.

\begin{tabular}{|c|c|c|c|c|c|c|c|c|c|}
\hline \multirow[t]{2}{*}{ Station ID } & \multicolumn{2}{|c|}{ Velocity $\left(\mathrm{mm} \mathrm{yr}^{-1}\right)$} & \multicolumn{2}{|c|}{ Error } & \multirow[t]{2}{*}{ Station ID } & \multicolumn{2}{|c|}{ Velocity $\left(\mathrm{mm} \mathrm{yr}^{-1}\right)$} & \multicolumn{2}{|c|}{ Error } \\
\hline & $V_{\text {EAST }}$ & $V_{\text {NORTH }}$ & $V_{\text {EAST }}$ & $V_{\text {NORTH }}$ & & $V_{\text {EAST }}$ & $V_{\text {NORTH }}$ & $V_{\text {EAST }}$ & $V_{\text {NORTH }}$ \\
\hline AKDG & -19.5 & 5.7 & 0.1 & 0.1 & KDZU & -14.1 & 12.3 & 4.6 & 4.4 \\
\hline AMAS & -14.5 & 6.2 & 0.1 & 0.1 & KKAL & -20.1 & 1.5 & 0.1 & 0.1 \\
\hline ANRK & -22.1 & -0.5 & 0.1 & 0.1 & KRBK & -2.3 & 0.1 & 0.1 & 0.1 \\
\hline BDRG & -7.8 & 1.1 & 1.7 & 1.9 & KRBS & -6.4 & 5.2 & 1.8 & 2.1 \\
\hline BILE & -22.8 & -4.3 & 0.1 & 0.1 & KSTM & -1.9 & 0.6 & 0.1 & 0.1 \\
\hline BOLU & -12.8 & -0.2 & 0.1 & 0.1 & KURU & -0.9 & 0.5 & 0.1 & 0.1 \\
\hline BOYT & -2.5 & -0.1 & 0.1 & 0.1 & KVKK & -6.6 & 0.2 & 2.1 & 2.5 \\
\hline BRBY & -10.6 & 0.6 & 2.3 & 2.6 & KZDR & -18.7 & -4.5 & 2.1 & 2.3 \\
\hline BYKY & -6.1 & -0.7 & 1.5 & 1.8 & NAHA & -23.1 & -3.2 & 0.1 & 0.1 \\
\hline BYYY & -6.8 & -1.0 & 2.1 & 2.4 & ORMN & -0.6 & -4.4 & 1.8 & 2.0 \\
\hline CANK & -19.4 & 0.5 & 0.1 & 0.1 & OZBR & -14.4 & 1.8 & 2.2 & 2.6 \\
\hline CGCS & -19.2 & -0.4 & 3.5 & 3.7 & RDIY & -11.4 & 5.1 & 0.1 & 0.1 \\
\hline CMLD & -21.1 & -3.0 & 0.1 & 0.1 & SAM1 & -1.9 & 1.3 & 0.2 & 0.2 \\
\hline CORU & -17.2 & 3.1 & 0.1 & 0.1 & SAMN & 1.3 & -3.0 & 0.2 & 0.2 \\
\hline CYLC & -15.5 & 2.8 & 2.0 & 2.4 & SIH1 & -22.8 & -3.6 & 0.1 & 0.2 \\
\hline DVBY & -16.6 & -2.5 & 2.0 & 2.3 & SIHI & -22.8 & -3.6 & 0.1 & 0.2 \\
\hline EREN & -17.6 & -2.3 & 1.9 & 2.1 & SINP & -0.7 & 0.5 & 0.1 & 0.1 \\
\hline ESKS & -23.1 & -4.2 & 0.1 & 0.1 & SIVS & -18.8 & 7.0 & 0.1 & 0.1 \\
\hline FASA & -2.2 & 1.8 & 0.1 & 0.1 & SLYE & -8.2 & -1.7 & 2.0 & 2.3 \\
\hline GIRS & -1.0 & 2.1 & 0.1 & 0.1 & SRKY & -10.1 & -1.1 & 2.1 & 2.5 \\
\hline HCGR & -9.1 & 3.9 & 1.7 & 1.9 & SSEH & -12.8 & 6.1 & 0.1 & 0.1 \\
\hline HEND & -6.0 & -2.2 & 0.1 & 0.1 & SUNL & -20.4 & 2.4 & 0.1 & 0.1 \\
\hline HMMP & -14.9 & -2.5 & 2.0 & 2.0 & TOK1 & -18.4 & 6.4 & 0.1 & 0.1 \\
\hline HMSL & -13.4 & -5.8 & 1.8 & 2.1 & VEZI & -5.3 & 2.1 & 0.1 & 0.1 \\
\hline HYMN & -20.9 & -2.7 & 0.1 & 0.1 & YYLA & -12.2 & -3.3 & 1.9 & 2.1 \\
\hline IMLR & -11.5 & 1.6 & 2.3 & 2.6 & YZKV & -4.4 & 1.5 & 2.6 & 3.1 \\
\hline IZMT & -5.0 & -2.1 & 0.1 & 0.1 & ZONG & -0.5 & -0.7 & 0.1 & 0.1 \\
\hline
\end{tabular}

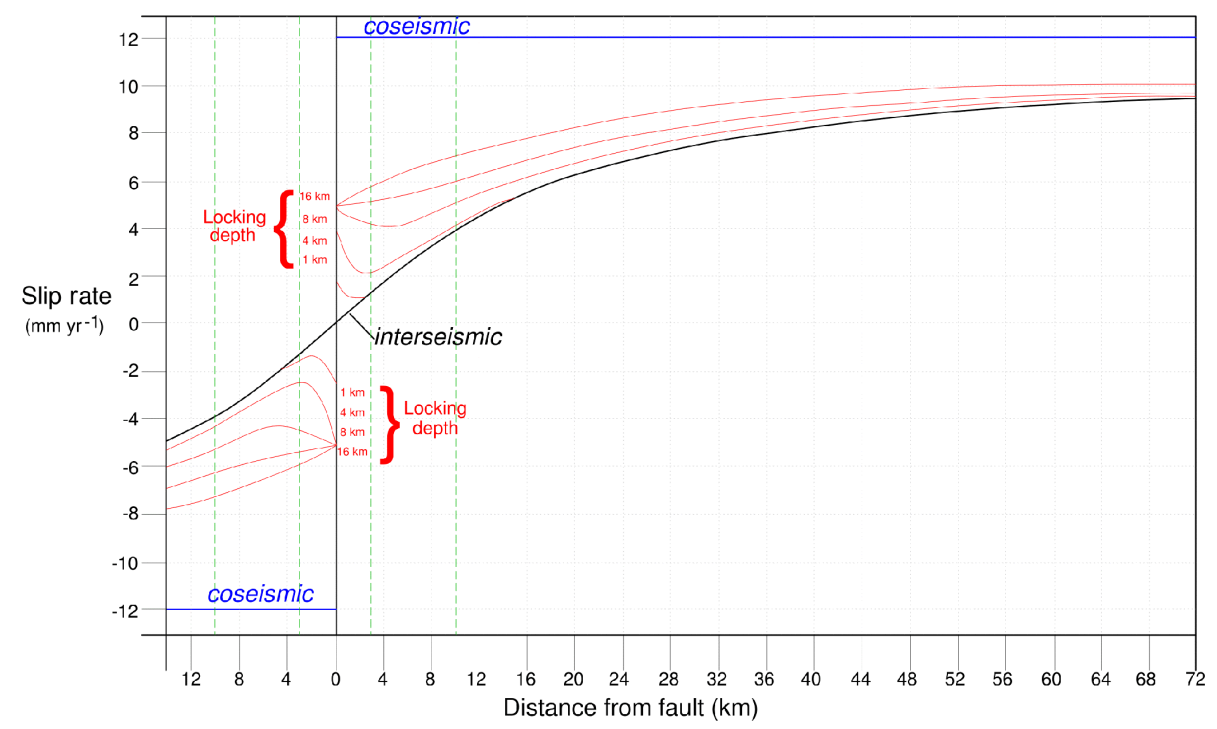

Figure 12. Slip rate along a fault plane during interseismic and coseismic events. Blue lines represent the coseismic events, and the black line represents the interseismic behavior; the red lines demonstrate the aseismic creep ratios at two sides of the fault for different locking depths. Green lines indicate 3 and $10 \mathrm{~km}$ on both sides of the fault where the interseismic behavior disintegrates from aseismic creep (after Yavasoglu et al., 2015). 


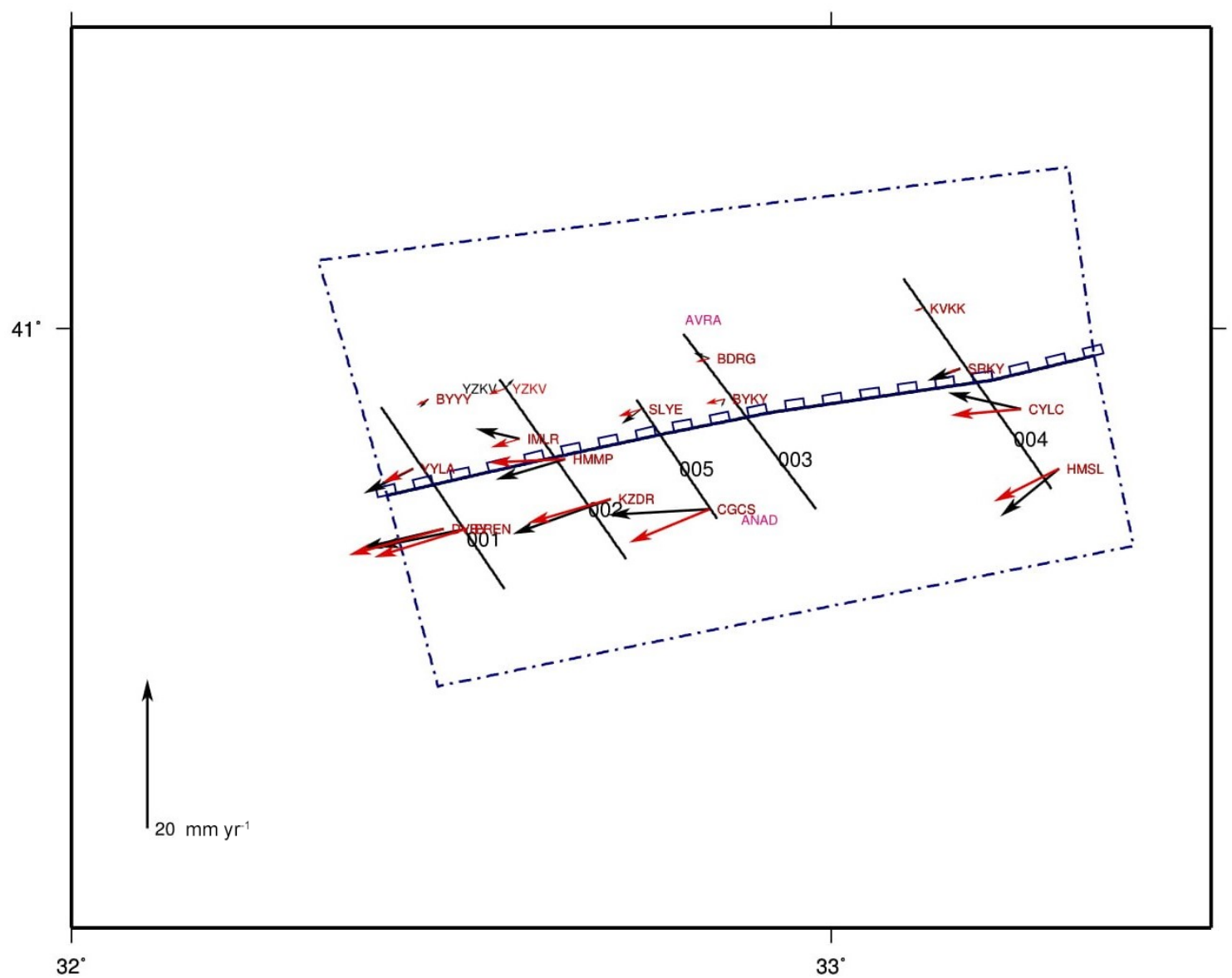

Figure 13. Model area for the İsmetpaşa segment with the Eurasian Plate (AVRA) on the north and the Anatolian Plate (ANAD) on the south (dashed lines), divided by the creeping segment of the NAF. Black and red arrows represent the observed and modeled velocities, respectively, obtained from GAMIT/GLOBK and TDEFNODE. Five profiles are numbered from west to east with 001 to 004 , with 005 representing the intermediate profile established during the first campaign. Two stations (SLYE and CGCS) on the south end of profile 003 were removed from the model due to unexpected velocities. Rectangles indicate the fault trace.

Table 7. Aseismic creep rate at the İsmetpaşa segment.

\begin{tabular}{lr}
\hline Profile & $\begin{array}{r}\text { Aseismic creep } \\
\text { rate }\left(\mathrm{mm} \mathrm{yr}^{-1}\right)\end{array}$ \\
\hline 001 & $14.0 \pm 3.0$ \\
002 & $14.9 \pm 3.6$ \\
005 (intermediate) & $14.0 \pm 4.0$ \\
004 & $10.1 \pm 3.0$ \\
\hline
\end{tabular}

eters. Therefore, the Euler pole is defined as $(0,0,0)$ for the Eurasian Plate and $(30.7,32.6,1.2)$ for the Anatolian Plate. The values represent latitude, longitude and angular velocity, respectively (McClusky et al., 2000).

Figure 12 demonstrates the suitable distances to detect aseismic creep. If an aseismic creep is suspected on a fault plane, then the optimum locations for the observation stations should be around 3 and $10 \mathrm{~km}$ on both sides of the fault and can be resolved from the interseismic movements. Therefore, the observation stations mentioned before are established around the fault as profiles to detect these discrepancies and to detect the main locking depth of the fault as well as attenuation depths for the creep event. Their locations are suitable to evaluate both the creeping ratios and locking depths of the faults.

\section{Discussion}

Station velocities all around the region indicate the motion of the Anatolian Plate relative to the Eurasian Plate. Movements range between 15 and $24 \mathrm{~mm} \mathrm{yr}^{-1}$ inside the southern plate where the northern motion reaches down to $\sim 1 \mathrm{~mm} \mathrm{yr}^{-1}$. That result is consistent with previous studies $\left(\sim 24 \pm 2 \mathrm{~mm} \mathrm{yr}^{-1}\right.$ ) (McClusky et al., 2000; Reilinger et al., 2006; Yavasoglu et al., 2011). In addition, model locking depths and results are similar to a more recent study 

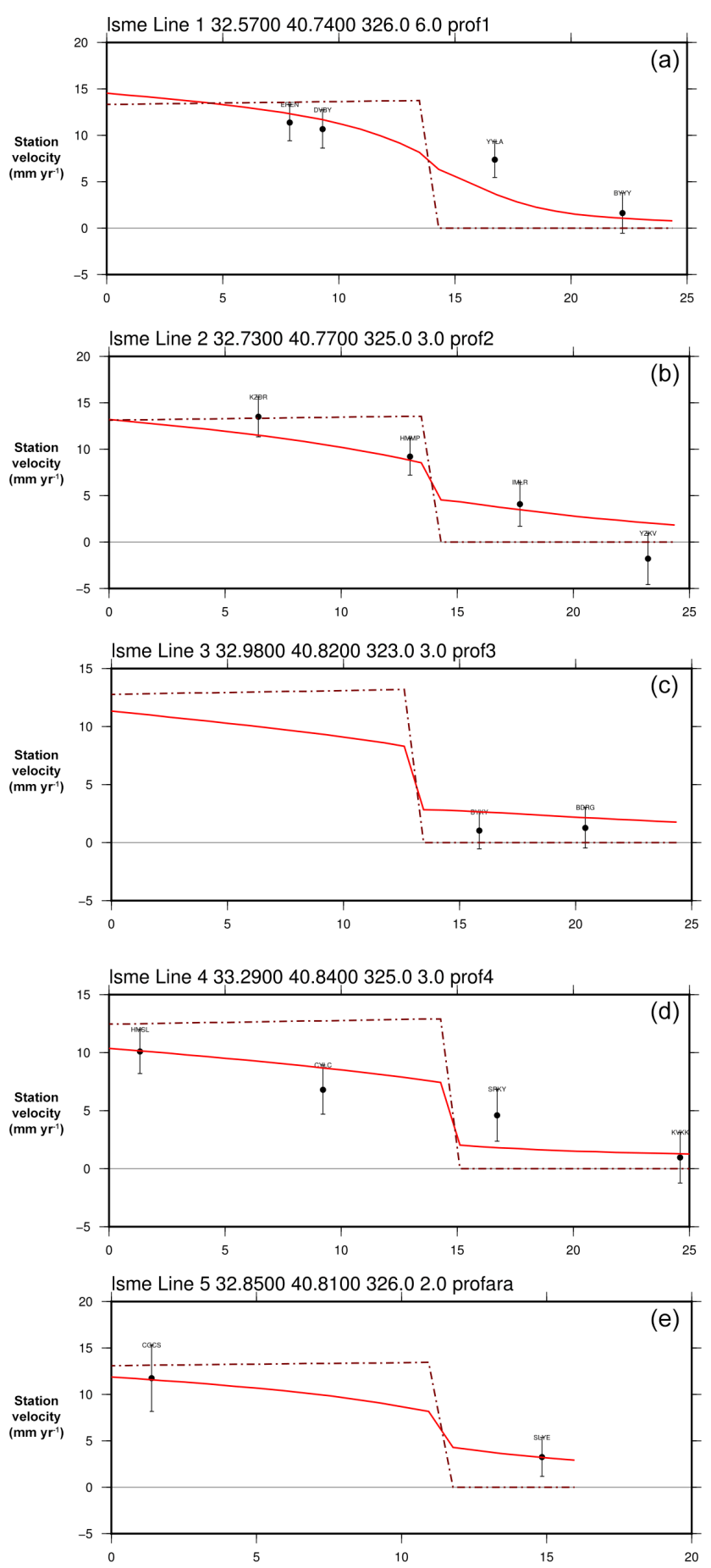

Figure 14. Station velocities at $25 \mathrm{~km}$ of distance for each side (east-west) through profiles 001-005. Each station is represented by a block dot; its code and error ratio are shown with vertical lines. Dashed lines are the block boundaries, and red lines are for the trend of velocity variations. Profiles 001-004 are shown in panels (a), (b), (c) and (d), respectively. The intermediate profile (005) is shown in (e). All the profiles are spread from south to north. with InSAR, which indicates that the locking depth of the fault at the İsmetpaşa segment is around $13-17 \mathrm{~km}$ and longterm tectonic movement is about $24-30 \mathrm{~mm} \mathrm{yr}^{-1}$ (Hussain et al., 2018).

Special features of the inspected segments are revealed by the network established near the fault plane. Regarding the surface velocities of the observation points, profiles on both the İsmetpaşa and Destek segments indicate movements. These range between $10.1-14.9$ and $10.6 \mathrm{~mm} \mathrm{yr}^{-1}$ for the İsmetpaşa and Destek segments, respectively.

Additionally, the modeled fault plane evaluation for observed and calculated station movements demonstrates similar results as the locking depths of both creeping and seismogenic layers (Fig. 13). Station velocities on the south of the NAF are faster than the north end as expected (Fig. 14). Regarding the long-term geodetic block motions, modeled weighted locking ratios indicate $13.0 \pm 3.3 \mathrm{~mm} \mathrm{yr}^{-1}$ of aseismic creep over the İsmetpaşa segment. That movement does not include the whole fault plane, and thus the creeping layer seems to slip freely to $4.5 \mathrm{~km}$ depths from the surface and decays between 4.5 and $6.75 \mathrm{~km}$. The seismic data and previous studies (Cakir et al., 2005; Yavaşoğlu et al., 2011; Hussain et al., 2018) indicate that the locking depth over the fault is $\sim 15 \mathrm{~km}$. This result demonstrates that the fully locked portion of the fault plane is between 6.75 and $15 \mathrm{~km}$, which is supported by the $\chi^{2}$ test result (1.00).

The Destek segment also has similar results for the observed and modeled velocities (Fig. 15). The surface velocities for the profile (006) at this region indicate velocity differences (Fig. 16). In addition, the modeled fault plane indicates that the creeping segment is limited to $4.3 \mathrm{~km}$ of depth from the surface and decays linearly between 4.3 and $6.0 \mathrm{~km}$. The remaining layer of the fault seems to be fully locked down to the seismogenic layer. The free-slipping portion has $9.6 \mathrm{~mm} \mathrm{yr}^{-1}$ of motion, which is similar to the estimated surface velocities $\left(10.6 \pm 3.1 \mathrm{~mm} \mathrm{yr}^{-1}\right)$. The $\chi^{2}$ test result $(1.01)$ and the seismic data confirm the accuracy of the model.

Moreover, paleomagnetic data indicate a predominantly clockwise rotation of the blocks bordered by the faults between the İsmetpaşa and Destek segments. Examining the results with this study promotes that behavior with the GPS field of the region, especially on the Anatolian side of the NAF (Figs. 13, 15) (İşseven and Tüysüz, 2006).

We find no clear evidence for attenuation at both segments. On the contrary, there is a slight increase at İsmetpaşa and almost $50 \%$ of an increase at Destek relative to previous studies. The frequency of this phenomenon at both segments is unclear, but the results of Hussain et al. (2018) support the argument that the creep event will continue until the next large-scale earthquake. 


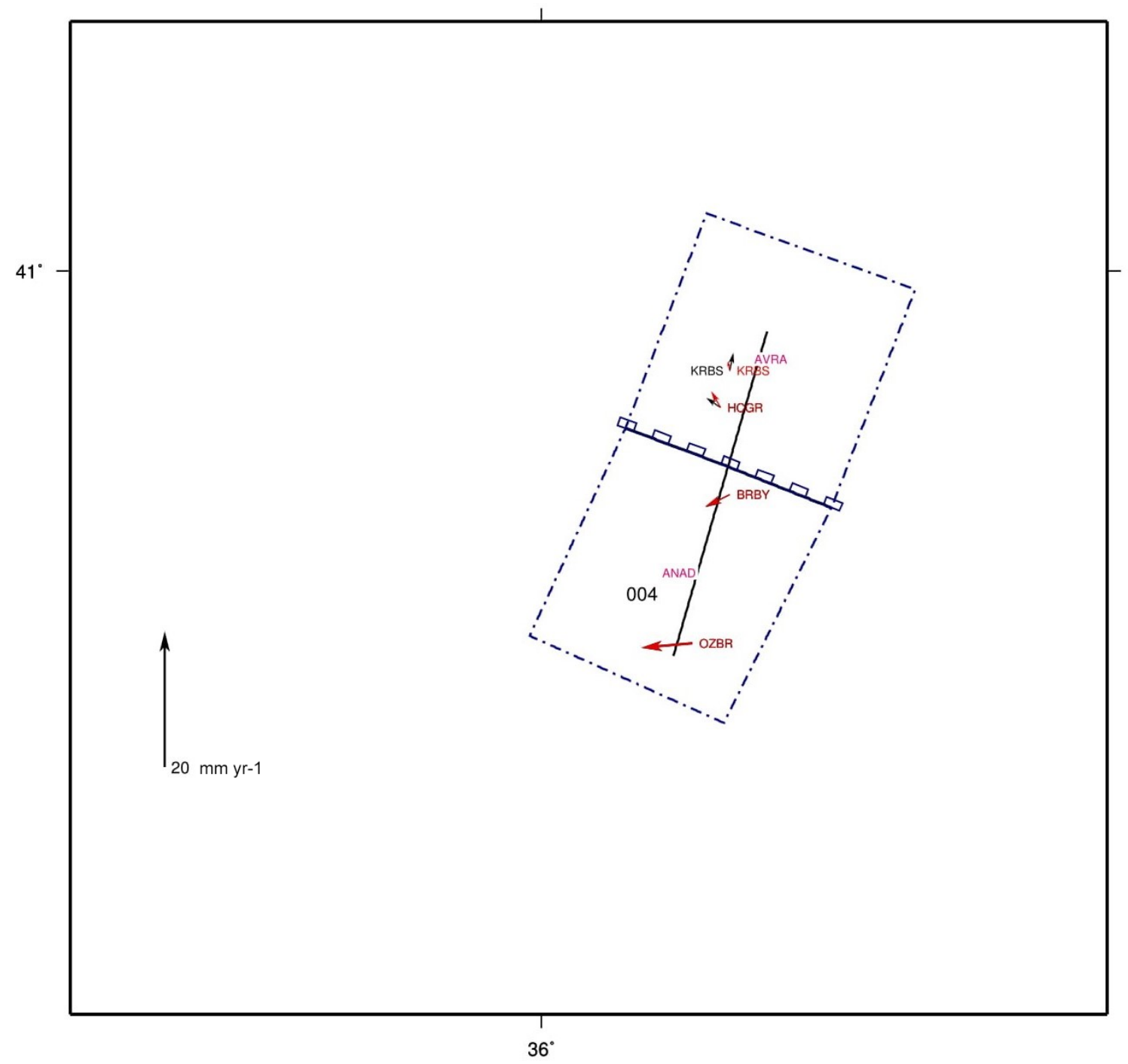

Figure 15. Model area for the Destek segment with the Eurasian Plate (AVRA) on the north and the Anatolian Plate (ANAD) on the south (dashed lines), divided by the creeping segment of the NAF. Black and red arrows represent the observed and modeled velocities, respectively, obtained from GAMIT/GLOBK and TDEFNODE. Profile 004 represents the area, and rectangles indicate the fault trace.

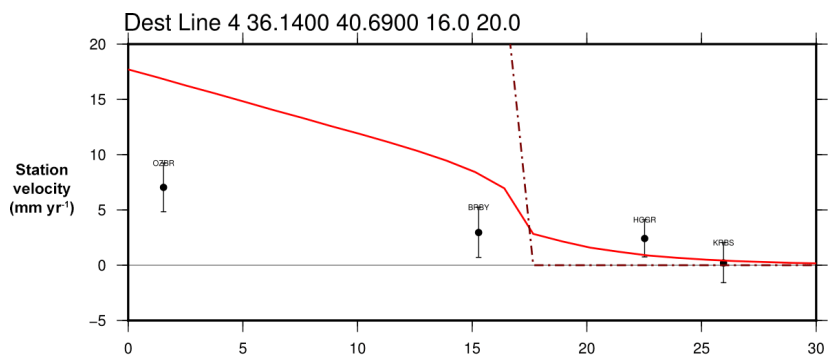

Figure 16. Station velocities and profile (006) for the Destek profile. Each station is represented by a block dot; its code and error ratio are shown with vertical lines. Dashed lines are the block boundaries, and red lines are for the trend of velocity variations. Profile spread from south to the north.

\section{Conclusions}

The NAF is reported to have had a creeping phenomena at İsmetpaşa since 1970 that has been observed with different techniques for a long time period, with a recent discovery at Destek. All previous studies concentrated on whole segments or at least some regions along those segments. With this study, a GPS network covering the whole Anatolian region along the NAF is established for the first time, and the results for the velocity area were used as input for block modeling. Also, the first GPS network covering the Destek segment was established during this study.

The network design and location of the observation points were distinguished according to the main locking depth of the NAF and the attenuation depth for the aseismic creep 
event. Model results show similar outcomes for both the İsmetpaşa and Destek segments; the locking depth for those segments is $\sim 15 \mathrm{~km}$, and attenuation for the creeping layer depths varies between $\sim 4$ and $6 \mathrm{~km}$.

Through all the models, results for this study indicate that the creeping behavior still continues at both the İsmetpaşa and Destek segments, with a ratio of $13.0 \pm 3.3$ and $10.6 \pm 3.1 \mathrm{~mm} \mathrm{yr}^{-1}$, respectively. Block modeling and seismic data indicate that the creeping segment does not reach the bottom of the seismogenic layer $(\sim 15 \mathrm{~km})$ and is limited to some depths, which may not prevent a medium- to largescale earthquake in the long term. In addition, we found no evidence for the attenuation of aseismic creep. Also, the frequency of this movement at İsmetpaşa is unclear and it is not possible to predict the aseismic creep ratio precisely for the long term, but results might indicate a small increase in the trend relative to previous studies in the region.

Additionally, the creeping ratio seems to have increased almost $50 \%$ at the Destek segment since previous studies, which might indicate a relief at that segment. However, according to the model, aseismic creep is limited to some depths $(\sim 6.0 \mathrm{~km})$ and the creep ratio is smaller than the long-term block movements. The increasing trend is not sufficient to release all the strain in that segment. This might indicate strain accumulation on both ends of the segment.

The network established by this study should be monitored periodically for a precise assessment of the frequency of aseismic creep, which may include possible clues for a clear fault plane definition and earthquakes. In addition, results indicate that this creep event will be monitored until the next earthquake, which might reveal valuable information for fault zone layout models.

Data availability. Tables 3 and 6 supply adequate information about the final outputs of the process. Other raw observation data and additional information used in this study can be accessed through their official web sites.

Author contributions. HHY and MNA contrived and conducted the data acquisition. Data processes were performed by HHY, MNA, and SB. Article preparation was done by ÖA with contributions from all co-authors. All authors made valuable contributions in every stage of the study. Additional thanks are mentioned in the acknowledgements.

Competing interests. The authors declare that they have no conflict of interest.

Acknowledgements. This paper is based on the $\mathrm{PhD}$ thesis of Mehmet Nurullah Alkan with the title "Kuzey Anadolu Fayı (KAF) Bolu-Çankırıve Amasya Bölgelerindeki Asismik Tektonik Yapının Periyodik GPS Ölçümleri ile Belirlenmesi” (Determination of
Aseismic Tectonic Structure in the Bolu-Çankırıand Amasya Regions Through the North Anatolian Fault (NAF) with Periodic GPS Observations) and is supported by the Coordinatorship of Scientific Research Projects (BAP) of Hitit University (project no. MYO19001.14.001), Istanbul Technical University (project ID: 425, code: 38146), and Afyon Kocatepe University (project no. 38146). We would also like to thank all participants in this project who helped during the field and software processes. In addition, we appreciate the equipment and software support of Afyon Kocatepe University and Ibrahim Tiryakioglu. The maps in this paper were created by using the GMT scripts provided by TDEFNODE software (McCaffrey 2002, http://www.web.pdx.edu/ mccaf/defnode. html, last access: 20 December 2018; Wessel and Smith, 1995).

Financial support. This research has been supported by the Coordinatorship of Scientific Research Projects (BAP) of Hitit University (grant no. MYO19001.14.001), the Istanbul Technical University (grant no. 15.FEN.BİL.16), and Afyon Kocatepe Üniversitesi (grant no. 38146).

Review statement. This paper was edited by Lev Eppelbaum and reviewed by two anonymous referees.

\section{References}

Akbaş, B., Akdeniz, N., Aksay, A., Altun, İ., Balcı, V., Bilginer, E., Bilgiç, T., Duru, M., Ercan, T., Gedik, İ., Günay, Y., Güven, İ. H., Hakyemez, H. Y., Konak, N., Papak, İ., Pehlivan, Ş., Sevin, M., Şenel, M., Tarhan, N., Turhan, N., Türkecan, A., Ulu, Ü., Uğuz, M. F., and Yurtsever, A. ve diğerleri: Türkiye Jeoloji HaritasıMaden Tetkik ve Arama Genel Müdürlüğü Yayını, Ankara, Türkiye, 2002.

Aktuğ, B. and Çelik, R. N.: Jeodezik ölçüler ile deprem kaynak parametrelerinin belirlenmesi, İTÜ dergisi, 7, 89-102, 2008.

Aladoğan, K., Tiryakioğlu, İ., Yavaşoğlu, H., Alkan, R. M., Alkan, M. N., Köse, Z., İlçi, V., Ozulu, İ. M., Tombuş, F. E., and Şahin, M.: Kuzey Anadolu FayıBolu-Çorum Segmenti Boyunca Yer Kabuğu Hareketlerinin GNSS Yöntemiyle İzlenmesi, Afyon Kocatepe Üniversitesi Fen ve Mühendislik Bilimleri Dergisi, 17, 997-1003, https://doi.org/10.5578/fmbd.60762, 2017.

Altay, C. and Sav, H: Continuous creep measurement along the North Anatolian fault zone, B. Geol. Cong. Turkey, 6, 77-84, 1991.

Ambraseys, N. N.: Some characteristic features of the Anatolian fault zone, Tectonophysics, 9, 143-165, https://doi.org/10.1016/0040-1951(70)90014-4, 1970.

Aytun, A.: Creep measurements in the Ismetpaşa region of the North Anatolian Fault Zone, Multidis. App. Earthq. Predict., 2, 279292, https://doi.org/10.1007/978-3-663-14015-3_20, 1982.

Bilham, R., Ozener, H., Mencin, D., Dogru, A., Ergintav, S., Cakir, Z., Aytun, A., Aktug, B., Yilmaz, O., Johnson, W., and Mattioli, G.: Surface creep on the North Anatolian Fault at İsmetpaşa, Turkey, 1944-2016, J. Geophys. Res.-Solid Earth, 121, 74097431, https://doi.org/10.1002/2016JB013394, 2016.

Bohnhoff, M., Martinez-Garzon, P., Bulut, F., Stierle, E., and BenZion, Y.: Maximum earthquake magnitudes along different sec- 
tions of the North Anatolian fault zone, Technophysics, 674, 147-165, https://doi.org/10.1016/j.tecto.2016.02.028, 2016.

Cakir, Z., Akoglu, A. M., Belabbes, S., Ergintav, S., and Meghraoui, M.: Creeping along the İsmetpaşa section of the North Anatolian fault (Western Turkey): Rate and extent from InSAR, Earth Planet. Sci. Lett., 238, 225-234, https://doi.org/10.1016/j.eps1.2005.06.044, 2005.

Cakir, Z., Ergintav, S., Özener, H., Doğan, U., Akoglu, A. M., Meghraoui, M., and Reilinger, R.: Onset of aseismic creep on major strike-slip faults, Geology, 40/12, 1115-1118, https://doi.org/10.1130/G33522.1, 2012.

Cakmak, R.: Jeodezik çalışmalarla Marmara Bölgesinde deprem döngüsünün belirlenmesi ve modellerle açıklanması, Ph.D. thesis, İstanbul Teknik Üniversitesi Fen Bilimleri Enstitüsü, Turkey, 131 pp., 2010.

Cetin, E., Cakir, Z., Meghraoui, M., Ergintav, S., and Akoglu, A. M.: Extent and distribution of aseismic slip on the Ismetpaşa segment of the North Anatolian Fault (Turkey) from Persistent Scattere InSAR, Geochem. Geophys. Geosyst., 15, 2883-2894, https://doi.org/10.1002/2014GC005307, 2014.

Deguchi, T.: Detection of fault creep around NAF by InSAR time series analysis using PALSAR data, Proc. SPIE, 8179, 16, https://doi.org/10.1117/12.898478, 2011.

Deniz, R., Aksoy, A., Yalin, D., Seeger, H., and Hirsch, O.: Determination of crustal movement in Turkey by terrestrial geodetic methods, J. Geodynam., 18, 13-22, https://doi.org/10.1016/0264-3707(93)90024-Z, 1993.

DiZio, L. P.: Elastic block modelling of fault slip rates across Southern California, Macalester Journal of Physics and Astronomy, 4/1, Article 3, 2016.

Emre, Ö., Duman, T. Y., Özalp, S., Şaroğlu, F., Olgun, Ş., Elmac1, H., and Çan, T.: Active fault database of Turkey, Bull. Earthq. Eng., 16, 3229-3275, 2018.

Eren, K.: Strain analysis along the North Anatolian fault by using geodetic surveys, Bull. Geodesique, 58, 137-149, 1984.

Fialko, Y., Kaneko, Y., Tong, X., Sandwell, D. T., and Furuya, M.: Investigation of interseismic deformation along the central section of the North Anatolian fault (Turkey) using InSAR observations and earthquake-cycle simulations, American Geophysical Union, Fall Meeting abstract \#T31E-08, 2011.

Fraser, J., Pigati, J. S., Hubert-Ferrari, A., Vanneste, K., Avsar, U., and Altinok, S.: A 3000-Year Record of GroundRupturing Earthquakes along the North Anatolian Fault near Lake Ladik, Turkey, B. Seismol. Soc. Am., 99, 2651-2703, https://doi.org/10.1785/0120080024, 2009.

Görmüş, K. S.: Kuzey Anadolu Fayıİsmetpaşa segmentindeki krip hızıdeğişiminin izlenmesi, Ph.D. thesis, Zonguldak Karaelmas Üniversitesi Fen Bilimleri Enstitüsü, Turkey, 97 pp., 2011.

Halıcıoğlu, K., Özener, H., and Ünlütepe, A.: Fay parametreleri ve kontrol ağlarının tasarımı, 12.Türkiye Harita Bilimsel ve Teknik Kurultay1, Ankara, 11-15 May, 2009.

Herring, T., King, R. W., Floyd, M. A., and McClusky, S. C.: Global Kalman filter VLBI and GPS analysis program, Department of Earth Atmospheric, And Planetary Sciences, Massachusetts Institute of Technology, 2015a.

Herring, T., King, R. W., Floyd, M. A., and McClusky, S. C.: Introduction to GAMIT/GLOBK, Department of Earth, Atmospheric, And Planetary Sciences, Massachusetts Institute of Technology, 2015 b.
Hussain, E., Wright, T. J., Walters, R. J., Bekaert, D. P. S., Lloyd, R., and Hooper, A.: Constant strain accumulation rate between major earthquakes on the North Anatolian Fault, Nat. Commun., 9, 1392, https://doi.org/10.1038/s41467-018-03739-2, 2018.

İşseven, T. and Tüysüz, O.: Paleomagnetically defined rotations of fault-bounded continental block in the North Anatolian Shear Zone, North Central Anatolia, J. Asian Earth Sci., 28, 469-479, https://doi.org/10.1016/j.jseaes.2005.11.012, 2006.

Karabacak, V., Altunel, E., and Cakir, Z.: Monitoring aseismic surface creep along the North Anatolian Fault (Turkey) using ground-based LIDAR, Earth Planet. Sci. Lett., 304, 64-70, https://doi.org/10.1016/j.epsl.2011.01.017, 2011.

Kaneko, Y., Fialko, Y., Sandwell, D. T., Tong, X., and Furuya, M.: Interseismic deformation and creep along the central section of the North Anatolian Fault (Turkey): InSAR observations and implications for rate-and-state friction properties, J. Geophys. Res.-Solid Earth, 118, 316-331, https://doi.org/10.1029/2012jb009661, 2013.

Ketin, İ.: Kuzey Anadolu Fayıhakkında, Maden Tetkik ve Arama Dergisi, 1969.

Ketin, İ.: San Andreas ve Kuzey Anadolu Faylarıarasında bir karşılaştırma, Türkiye Jeoloji Kurumu Bülteni, 19, 149-154, 1976.

Köksal, E. Yüzey deformasyonlarının Diferansiyel InSAR Tekniği ile Belirlenmesi: İsmetpaşa Örneği. Ph.D. thesis, Zonguldak Karaelmas Üniversitesi Fen Bilimleri Enstitüsü, Turkey, 136 pp., 2011.

Kutoglu, H .S. and Akcin, H.: Determination of the 30-year creep trend on the Ismetpaşa segment of the North Anatolian Fault using an old geodetic network, Earth Planets Space, 58, 937-942, https://doi.org/10.1186/BF03352598, 2006.

Kutoglu, H. S., Akcin, H., Kemaldere, H., and Gormus, K. S.: Triggered creep rate on the İsmetpaşa segment of the North Anatolian Fault, Nat. Hazards Earth Syst. Sci., 8, 1369-1373, https://doi.org/10.5194/nhess-8-1369-2008, 2008.

Kutoğlu, H. Ş., Akçın, H., Görmüş, K. S., and Kemaldere, H.: Kuzey Anadolu Fayıİsmetpaşa segmentinde gerçekleştirilen jeodezik çalışmalar, 12.Türkiye Harita ve Bilimsel Kurultayı, Ankara, 11-15 May, 2009.

Kutoglu, H. S., Akcin, H., Gundogdu, O., Gormus, K. S., and Koksal, E.: Relaxation on the İsmetpaşa segment of the North Anatolian Fault after the Golcuk $M_{\mathrm{W}}=7.4$ and Duzce $M_{\mathrm{W}}=$ 7.2 shocks, Nat. Hazards Earth Syst. Sci., 10, 2653-2657, https://doi.org/10.5194/nhess-10-2653-2010, 2010.

Kutoglu, H. S., Gormus, K. S., Deguchi, T., Koksal, E., Kemaldere, H., and Gundogdu, O.: Can a creeping segment become a monitor before destructive major earthquakes, Nat. Hazards, 65, 2161-2173, https://doi.org/10.1007/s11069-012-0466-0, 2013.

McCaffrey, R.: Crustal block rotations and plate coupling, Plate Boundary Zones, Geodynam. Series, 30, 101-122, https://doi.org/10.1029/GD030p0101, 2002.

McCaffrey, R.: Time-dependent inversion of three-component continuous GPS for steady and transient sources in northern Cascadia, Geophys. Res. Lett., 36-37, L07304, https://doi.org/10.1029/2008GL036784, 2009.

McCaffrey, R.: Interseismic locking on the Hikurangi subduction zone: Uncertainties from slow-slip events, J. Geophys. Res.-Solid Earth, 119, 7874-7888, https://doi.org/10.1002/2014JB010945, 2014. 
McClusky, S., Balassanian, S., Barka, A., Demir, C., Ergintav, S., Georgiev, I., Gurkan, O., Hamburger, M., Hurst, K., Kahle, H., Kastens, K., Kekelidze, G., King, R., Kotzev, V., Lenk, O., Mahmoud, S., Mishin, A., Nadriya, M., Ouzounis, A., Paradissis, D., Peter, Y., Prilepin, M., Reilinger, R., Sanli, I., Seeger, H., Tealeb, A., Toksoz, M. N., and Veis, G.: Global Positioning System constraints on plate kinematics and dynamics in the eastern Mediterranean, J. Geophys. Res., 105, 5695-5719, https://doi.org/10.1029/1996JB900351, 2000.

Okada, Y.: Internal deformation due to shear and tensile faults in a half-space, B. Seismol. Soc. Am., 75, 1135-1154, 1985.

Ozener, H., Dogru, A., and Turgut, B.: Quantifying aseismic creep on the İsmetpaşa segment of the North Anatolian Fault Zone(Turkey) by 6 years of GPS observations, J. Geodynam., 67, 72-77, https://doi.org/10.1016/j.jog.2012.08.002, 2013.

Poyraz, F., Tatar, O., Hastaoğlu, K.Ö., Türk, T., Gürsoy, T., Gürsoy, Ö., and Ayazlı, İE.: Elastik atım teorisi: Kuzey Anadolu Fay Zonu örneği, 13.Türkiye Harita Bilimsel ve Teknik Kurultayı, Ankara, 18-22 April, 2011.

Reid, H. F.: The Mechanics of the Earthquake, The California Earthquake of April 18, 1906. Report of the State Investigation Commission, Carnegie Institution of Washington, 2, 16-28, 1910.

Reilinger, R., McClusky, S., Vernant, P., Lawrance, S., Ergintav, S., Cakmak, R., Ozener, H., Kadirov, F., Guliev, I., Stepanyan, R., Nadariya, M., Habubia, G., Mahmoud, S., Sakr, K., ArRajehi, A., Paradissis, D., Al-Aydrus, A., Prilepin, M., Guseva, T., Evren, E., Dmitrosa, A., Filikov, S.V., Gomez, F., Al-Ghazzi, R., and Karam, G.: GPS constraints on continental deformation in the Africa-Arabia, Eurasia continental collision zone and implications for the dynamics of plate interactions, J. Geophys. Res.-Solid Earth, 111, B05411, https://doi.org/10.1029/2005JB004051, 2006.

Rousset, B., Jolivet, R., Simons, M., Lasserre, C., Riel, B., Milillo, P., Çakir, Z., and Renard, F.: An aseismic slip transient on the North Anatolian Fault, Geophys. Res. Lett., 43, 3254-3262, https://doi.org/10.1002/2016GL068250, 2016.
Şaroğlu, F. and Barka, A.: Deprem sonrasıdevam eden uzun dönem yerdeğiştirmelerin anlamıve önemi, Jeofizik, 9, 339-343, 1995.

Schmidt, D. A., Bürgmann, R., Nadeau, R. M., and d'Alessio, M.: Distribution of aseismic slip rate on the Hayward fault inferred from seismic and geodetic data, J. Geophys. Res., 110, B08406, https://doi.org/10.1029/2004JB003397, 2005.

Şengör, A. M. C., Tüysüz, O., İmren, C., Sakınç, M., Eyidoğan, H., Görür, N., Pichon, X. L., and Rangin, C.: The North Anatolian Fault: A new look, Annu. Rev. Earth Planet, 33, 37-112, https://doi.org/10.1146/annurev.earth.32.101802.120415, 2005.

Taskin, G., Uskuplu, S., Saygin, H., and Ergintav, S.: Optimization of GPS observation strategy for improvement of tectonic measurements. The IASTED International Conference on Applied Simulation and Modelling, Spain, 3-5 September, 2003.

Wei, M., Sandwell, D., Fialko, Y., ad Bilham, R.: Slip on faults in the Imperial Valley triggered by the 4 April $2010 M_{\mathrm{W}} 7.2 \mathrm{El}$ Mayor-Cucapah earthquake revealed by InSAR, Geophys. Res. Lett., 38, L01308, https://doi.org/10.1029/2010g1045235, 2011.

Wessel, P. and Smith, W. H. F.: New version of the generic mapping tools released. EOS Transactions - American Geophysical Union 76, 329, 1995.

Yavasoglu, H., Alkan, M. N., Ozulu, I. M., Ilci, V., Tombus, F. E., Aladogan, K., Sahin, M., Tiryakioglu, I., and Kivrak, S. O.: Recent tectonic features of the central part (Bolu-Corum) of the North Anatolian Fault, Hittite J. Sci. Eng., 2/1, 77-83, https://doi.org/10.17350/HJSE19030000011, 2015.

Yavaşoğlu, H., Tarı, E., Tüysüz, O., Çakır, Z., and Ergintav, S.: Determining and modeling tectonic movements along the central part of the North Anatolian Fault (Turkey) using geodetic measurements, J. Geodynam., 51, 339-343, https://doi.org/10.1016/j.jog.2010.07.003, 2011. 